\title{
The synthesis of 2,3,5-trisubstituted phenols
}

\author{
Alan R. Katritzky,* Yu Ji, Dmytro O. Tymoshenko, Yunfeng Fang, and Keisha-Gay \\ Hylton
}

Center for Heterocyclic Compounds, University of Florida, Department of Chemistry, Gainesville, Florida 32611-7200, USA

E-mail: Katritzky@chem.ufl.edu

\section{Dedicated to Prof. Alfred Hassner on the occasion of his $\mathbf{7 0}^{\text {th }}$ birthday}

(received 18 Jan 01; accepted 28 Oct 01; published on the web 05 Nov 01)

\begin{abstract}
Synthetic route to 2,3,5-trisubstituted phenols based on two-step $[1+2+3]$ construction of the phenol backbone from 1-[(trimethylsilyl)methyl]-1H-1,2,3-benzotriazole, aliphatic or arylacetic acid chlorides and chalcones or $\alpha, \beta$-unsaturated- $\gamma$-diketones was developed. 2,3,5-Trisubstituted phenols 8, 9a-e, 10a-d, 12a-e were successfully synthesized.
\end{abstract}

Keywords: 2,3,5-Trisubstituted phenols, 1-[(trimethylsilyl)methyl]-1H-1,2,3-benzotriazole, chalcones, $\alpha, \beta$-unsaturated- $\gamma$-diketones

\section{Introduction}

ortho-Aryl-substituted phenols are important ligands used in organometallic chemistry to increase the stereo-, regio-and chemo-selectivity of catalytic processes. ${ }^{\text {a-d }}$ Phenols are also valuable precursors, e.g. for oxidation ${ }^{2 \mathrm{a}-\mathrm{d}}$ into polysubstituted quinones which are potent biocides. $^{3 \mathrm{a}-\mathrm{d}}$

Synthetic strategies used for the preparation of 2,3,5-polysubstituted phenols include the following multistep sequences: (i) from pyrylium salts and nitromethane ${ }^{4}$ and (ii) by basecatalyzed reactions of pre-formed ethynyl ketones with benzyl ketones. ${ }^{5}$

Our recent study of [3+3] annulation reactions of 1-(benzotriazol-1-yl)propan-2-one with chalcones $^{6}$ gave an access to 3,5-diarylphenols advantageous as compared to the previously reported aromatization of cyclohexenones ${ }^{7 \mathrm{a}, \mathrm{b}}$ and Michael addition/aldol condensation of 1-(2oxopropyl)pyridiniums salts with chalcones. ${ }^{8}$ No general method has previously been described for the preparation of meta-acylphenols, few of which are known. ${ }^{9 \mathrm{acc}} \mathrm{We}$ have now generalized our previous approach ${ }^{6}$ to obtain 2,3,5-trisubstituted phenols 9a-e, 10a-d and 11c-d via stepwise $[1+2+3]$ formation of the phenol backbone from "aliphatic" building blocks (Scheme 1). Our 
sequence affords 1-(benzotriazol-1-yl)-2-ones 3a-g in high yields from the one-carbon synthon 1-[(trimethylsilyl)methyl]-1H-1,2,3-benzotriazole $(\mathbf{1})^{10}$ by heating neat with aliphatic or arylacetic acid chlorides 2a-g. Compared to the previous preparation of $\mathbf{3}$ from $\alpha$-haloketones ${ }^{6}$, the new approach broadened the variety of available intermediates 3 . Thus, compound $3 \mathbf{e}$ on treatment with $\mathrm{MeI}$ and $5 \mathrm{M} \mathrm{NaOH}$ in acetonitrile affords compound 4. Compounds 3a-g and 4 react with $\alpha, \beta$ - unsaturated ketones to form tri-substituted phenols 12a-e and $\mathbf{8}$ with points of diversity at the 2,3 , and 5 positions (Scheme 1).

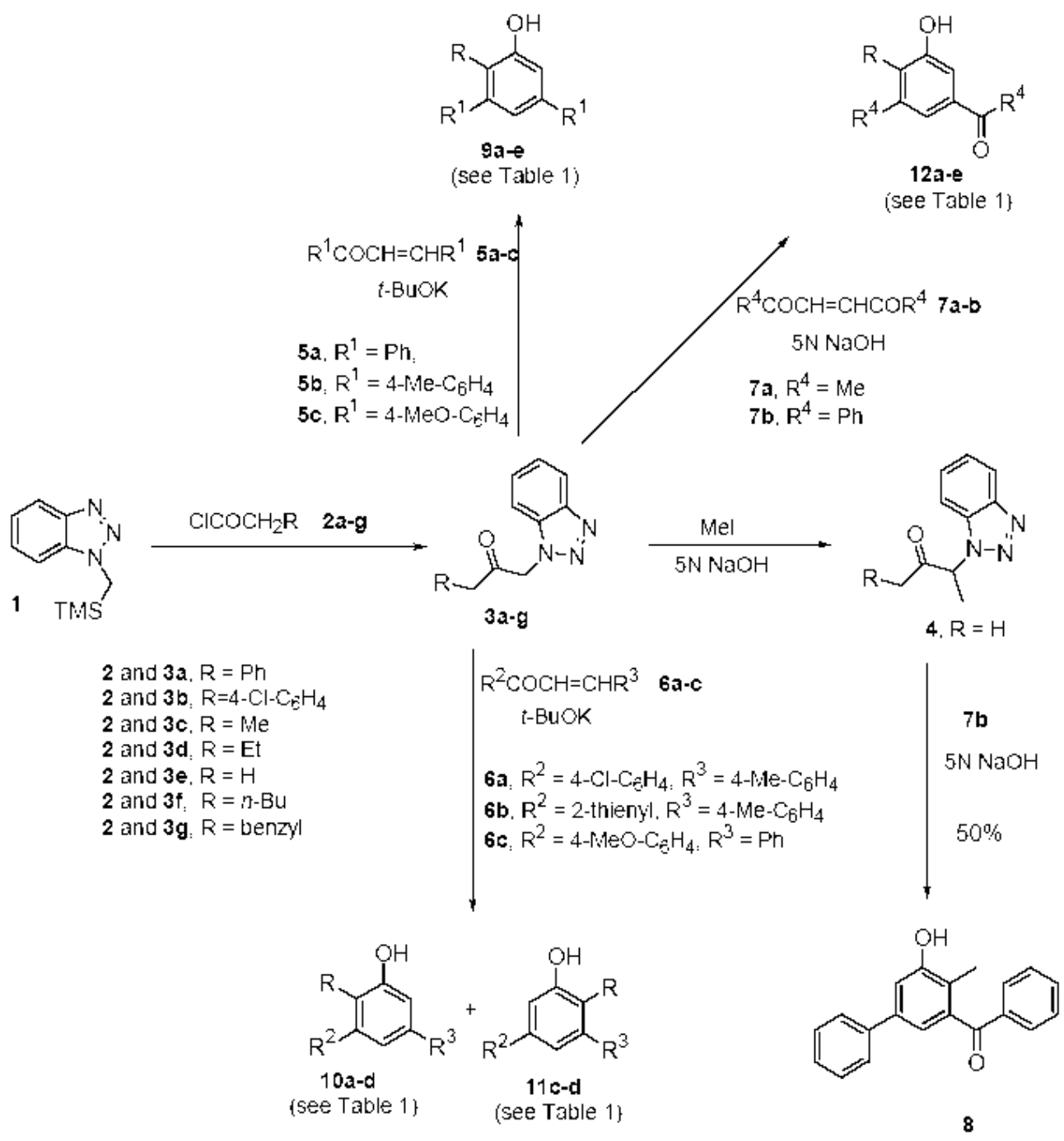

\section{Scheme 1}

\section{Results and Discussion}

The reactions of the intermediates 3a-g or $\mathbf{4}$ and $\alpha, \beta$-unsaturated ketones are discussed in several separate subsections according to the proposed reaction mechanisms reported earlier. ${ }^{6}$ 
(i) The reactions of intermediates 3a-c with the symmetrical chalcones $5 a, b$ or c. Treatment of the mixture of each intermediate $\mathbf{3 a - c}$ and the appropriate chalcone $\mathbf{5 a}$, $\mathbf{b}$ or $\mathbf{c}$ in $n$ butanol with 2 equiv. of potassium tert-butoxide and refluxing for $48 \mathrm{~h}$ gave 2,3,5-trisubstituted phenols 9a-e in good yields (Table 1). The structures of 9a-e were assigned by their ${ }^{1} \mathrm{H}$ NMR and ${ }^{13} \mathrm{C}$ NMR spectra: only one new set of signals was found.

In the ${ }^{1} \mathrm{H}$ NMR of 9a, the three singlets at $2.07 \mathrm{ppm}, 2.26 \mathrm{ppm}$ and $2.30 \mathrm{ppm}$ were assigned to the three methyl groups of 9a; in the ${ }^{13} \mathrm{C}$ NMR of 9a, the signals of these groups appear at $12.8 \mathrm{ppm}, 21.0 \mathrm{ppm}$ and $21.1 \mathrm{ppm}$. In the ${ }^{1} \mathrm{H}$ NMR and ${ }^{13} \mathrm{C}$ NMR spectra of the phenols $9 \mathbf{b}-\mathbf{e}$, we have also found only one set of proton and carbon signals in each case, this confirming that the sequence afforded a single product. There are some differences in the acidity of the active methylenes alpha to the carbonyl in the intermediates 3a-c, depending on whether $\mathrm{R}$ is an aliphatic group or an aromatic group, but that had no affect on the reactions of symmetrical chalcones 5a,b,c, which gave only one final product.

(ii) The reactions of intermediates $3 a$, c, or $\mathbf{d}$ with unsymmetrical chalcones $6 a, b$, or $c$. When the intermediates 3a,c or $\mathbf{d}$ reacted with the chalcones $\mathbf{6 a - c}$ under the same conditions as used for the preparation of 9a-e, the results obtained varied as follows.

a) The reaction of the intermediate $\mathbf{3 c}$ or $\mathbf{3 d}$ with chalcone $\mathbf{6 c}$ afforded 2,3,5-trisubstituted phenols 10a and 10b, respectively. Structures 10a,b were assigned by their ${ }^{1} \mathrm{H} N \mathrm{NR}$ and ${ }^{13} \mathrm{C}$ NMR spectra; only one new set of signals could be observed. In the ${ }^{1} \mathrm{H}$ NMR spectrum of 10a, the singlet at $2.20 \mathrm{ppm}$ was assigned to the methyl group of 10a; in the ${ }^{13} \mathrm{C} N M R$ of $10 a$, the signal at $21.0 \mathrm{ppm}$ was assigned to the same group. In the ${ }^{1} \mathrm{H} \mathrm{NMR}$ of $\mathbf{1 0 b}$, the triplet at 1.06 ppm and the quartet at $2.61 \mathrm{ppm}$ were assigned to the ethyl group of $\mathbf{1 0 b}$; in the ${ }^{13} \mathrm{C} \mathrm{NMR}$ of $\mathbf{1 0 b}$, the signals of this group appear at $14.4 \mathrm{ppm}$ and $21.0 \mathrm{ppm}$. According to our previous mechanistic study ${ }^{6}$, if substituent $\mathrm{R}$ in a compound 3 is aliphatic, the pronounced difference in reactivities of the two methylenes alpha to the carbonyl, caused by the strong electronwithdrawing ability of the benzotriazole group, results in the regiospecificity of these reactions.

b) The reactions of the intermediate 3a with chalcones $\mathbf{6 a}$ or $\mathbf{6 b}$ gave inseparable mixtures of regioisomers 10c/11c and $\mathbf{1 0 d} / \mathbf{1 1 d}$, respectively. In the ${ }^{1} \mathrm{H}$ NMR spectra of each of these mixtures, two singlets were found near $2.00 \mathrm{ppm}$, which were assigned to the methyl groups. The ratio of compound $\mathbf{1 0 c}$ to $11 \mathrm{c}$ is $4: 1$, while the ratio of compound $\mathbf{1 0 d}$ to $11 \mathrm{~d}$ is $1.6: 1$ according to the peak areas of the methyl groups in the ${ }^{1} \mathrm{H}$ NMR spectra. Two sets of signals could also be found in the ${ }^{13} \mathrm{C}$ NMR spectra: at $21.7 \mathrm{ppm}$ and $21.0 \mathrm{ppm}$ for the mixture of 10c and 11c, at 20.9 ppm and 21.0 ppm for the mixture of 10d and 11d. These observed ratios for 10c,d and 11c,d can be explained according to the high reactivity of the benzylic protons of 3a, which react via a 1,4-addition pathway with chalcones $\mathbf{6 a}$ or $\mathbf{6 b}$. Thus, for $3 \mathbf{a}$ with $\mathrm{R}$ equal to phenyl, the regioselectivity of the reaction decreased and two regioisomers were obtained.

(iii) The reaction of intermediate 4 with $\alpha, \beta$-unsaturated- $\gamma$-diketone $7 \mathbf{b}$. Treatment of the intermediate 4 with $\alpha, \beta$-unsaturated- $\gamma$-diketone $\mathbf{7 b}$ in acetonitrile in the presence of $5 \mathrm{~N} \mathrm{NaOH}$ at room temperature overnight gave 2,3,5-trisubstituted phenol 8 in $50 \%$ yield (Table 1). In the ${ }^{1} \mathrm{H}$ NMR spectrum of the product, only one singlet at about 2.00 ppm could be found, which was 
assigned to the methyl group of the phenol 8. In the ${ }^{13} \mathrm{C}$ NMR spectrum, there is also only one signal at $12.9 \mathrm{ppm}$ and it was assigned to the same group. As in this case $\mathrm{R}$ is an aliphatic group, there is a large difference between reactivities of the two positions alpha to the carbonyl group in the intermediate 4 . Thus, this reaction is regiospecific, and only one product 8 was obtained. However, one point is noteworthy: the reaction of $\alpha, \beta$-unsaturated diketone with $\alpha$-substituted $\alpha$ benzotriazolylmethyl ketones is very sensitive to the size of the $\alpha$-substituent. For example, the yield of the compound $\mathbf{8}$ in this reaction (50\%) is significantly lower than the yield of the analogous 2-unsubstituted product 12b (90\%) (Table 1). When 3-(1H-1,2,3-benzotriazol-1-yl)-2pentanone 3d bearing the ethyl group in the $\alpha$-position reacted with the compound $\mathbf{7 b}$, the only result was a complex reaction mixture, which contained less than $10 \%$ of the desired product according to $\mathrm{GC} / \mathrm{MS}$.

(iv) The reactions of intermediates $3 c, e, f, g$ with $\alpha, \beta$-unsaturated- $\gamma$-diketones $7 a, b$. The reactions of $\alpha$-benzotriazolylmethyl ketones 3c,e,f,g, with $\alpha, \beta$-unsaturated- $\gamma$ diketones $7 \mathbf{a}$ or $7 \mathbf{b}$ in acetonitrile in the presence of $5 \mathrm{~N} \mathrm{NaOH}$ gave 2,3,5-trisubstituted phenols 12a-e in yields of $33 \%-90 \%$. The ${ }^{1} \mathrm{H}$ NMR spectra of 12a-e each showed only one set of signals for the appropriate protons. For example, in the ${ }^{1} \mathrm{H}$ NMR spectrum of product the 12a, two singlets at $2.34 \mathrm{ppm}$ and 2.57 ppm were assigned for the two methyl groups. In the ${ }^{13} \mathrm{C} N M R$ of 12a, the signals of these groups appear at $10 \mathrm{ppm}-60 \mathrm{ppm}$. This demonstrated that this reaction sequence gives only one product.

Each of the two carbonyl groups present in $\alpha, \beta$-unsaturated- $\gamma$-diketones 7a,b could be involved in a 1,4 conjugated addition. However, because both $\alpha, \beta$-unsaturated- $\gamma$-di-ketones 7a,b are symmetrical and $\mathrm{R}$ in compounds $3 \mathbf{c}, \mathbf{e}, \mathbf{f}, \mathbf{g}$ are aliphatic, thus providing a marked reactivity differences between two methylene groups $\alpha$ to the carbonyl group in the intermediates 3c,e,f,g, these reactions are regiospecific.

These reactions can be further divided into two classes according to the $\mathrm{R}^{4}$ substituent: i) when $\mathrm{R}^{4}$ is a methyl group, the $\alpha, \beta$-unsaturated- $\gamma$-diketone $7 \mathbf{a}$ reacted with the intermediate $3 \mathbf{e}$ to give the product 12a in 33\% yield; the low yield perhaps could be explained by the low stability of 7a under basic conditions; ii) when $\mathrm{R}^{4}$ is a phenyl group, the reaction of $\alpha, \beta$-unsaturated- $\gamma$ diketone $\mathbf{7 b}$ with intermediates $\mathbf{3 c , e , f , g}$ gave the products $\mathbf{1 2 b}$-e respectively, with excellent yields for $\mathbf{1 2 b}, \mathbf{c}(\mathrm{R}=\mathrm{H}$ or $\mathrm{Me})$ and moderate yields for $\mathbf{1 2 d , e}(\mathrm{R}=n-\mathrm{Bu}$ or benzyl) (Table 1).

These results demonstrate the effect of the $\mathrm{R}$ substituent: increasing bulk of the $\mathrm{R}$ group decreases product yield. Sodium hydroxide as a base in this reaction of $\mathbf{3}$ with $\mathbf{7}$ is preferable to potassium tert-butoxide. Being a strong enough base to complete the reaction successfully, sodium hydroxide does not cause the formation of byproducts, which could arise from the subsequent reactions of the acyl group in the products 12. On the other hand, the preparation of compound 12b using potassium tert-butoxide as a base afforded it only in $30 \%$ yield. However, the reactions of $\mathbf{3}$ with less reactive chalcones (discussed above) require stronger base, and in this case potassium tert-butoxide is preferable. (Scheme 2) 
Table 1. Preparation of 2,3,5-trisubstituted phenols 9a-e, 10a-d, 11c-d and 12a-e

\begin{tabular}{|c|c|c|c|c|c|c|}
\hline Phenols & $\mathrm{R}$ & $\mathrm{R}^{1}$ & $\mathrm{R}^{2}$ & $\mathrm{R}^{3}$ & $\mathrm{R}^{4}$ & Yield \% \\
\hline $9 a$ & $\mathrm{Me}$ & 4-Me- $\mathrm{C}_{6} \mathrm{H}_{4}$ & - & - & - & 48 \\
\hline $9 b$ & $\mathrm{Ph}$ & $\mathrm{Ph}$ & - & - & - & 89 \\
\hline 9c & $\mathrm{Ph}$ & $4-\mathrm{Me}-\mathrm{C}_{6} \mathrm{H}_{4}$ & - & - & - & 43 \\
\hline 9d & $\mathrm{Ph}$ & 4-MeO- $\mathrm{C}_{6} \mathrm{H}_{4}$ & - & - & - & 86 \\
\hline $9 e$ & $4-\mathrm{Cl}-\mathrm{C}_{6} \mathrm{H}_{4}$ & $4-\mathrm{Me}-\mathrm{C}_{6} \mathrm{H}_{4}$ & - & - & - & 43 \\
\hline $10 a$ & $\mathrm{Me}$ & - & $4-\mathrm{MeO}-\mathrm{C}_{6} \mathrm{H}_{4}$ & $\mathrm{Ph}$ & - & 50 \\
\hline $10 \mathrm{~b}$ & Et & - & $4-\mathrm{MeO}-\mathrm{C}_{6} \mathrm{H}_{4}$ & $\mathrm{Ph}$ & - & 65 \\
\hline $10 c+11 c$ & $\mathrm{Ph}$ & - & $4-\mathrm{Cl}-\mathrm{C}_{6} \mathrm{H}_{4}$ & $4-\mathrm{Me}-\mathrm{C}_{6} \mathrm{H}_{4}$ & - & 49 \\
\hline $10 d+11 d$ & $\mathrm{Ph}$ & - & 2-thienyl & $4-\mathrm{Me}-\mathrm{C}_{6} \mathrm{H}_{4}$ & - & 49 \\
\hline 12a & $\mathrm{H}$ & - & - & - & $\mathrm{Me}$ & 33 \\
\hline 12b & $\mathrm{H}$ & - & - & - & $\mathrm{Ph}$ & 90 \\
\hline $12 \mathrm{c}$ & $\mathrm{Me}$ & - & - & - & $\mathrm{Ph}$ & 84 \\
\hline 12d & $n-\mathrm{Bu}$ & - & - & - & $\mathrm{Ph}$ & 62 \\
\hline $12 e$ & benzyl & - & - & - & $\mathrm{Ph}$ & 40 \\
\hline
\end{tabular}

In summary, a novel synthetic route to 2,3,5-trisubstituted phenols was developed based on the two-step $[1+2+3]$ construction of the phenol backbone from 1-[(trimethylsilyl)methyl]-1H$1,2,3$-benzotriazole, an aliphatic or arylacetyl acid chloride and a chalcones or $\alpha, \beta$-unsaturated- $\gamma$ diketone.

\section{Experimental Section}

General Procedures. Melting points were determined on a hot-stage apparatus and are uncorrected. NMR spectra were recorded in $\mathrm{CDCl}_{3}$ or DMSO-d ${ }^{6}$ with TMS as the internal standard for ${ }^{1} \mathrm{H}(300 \mathrm{MHz})$ or a solvent as the internal standard for ${ }^{13} \mathrm{C}(75 \mathrm{MHz})$. Microanalyses were performed on a Carlo Erba -1106 elemental analyzer. Benzene and toluene were dried over molecular sieves. Column chromatography was conducted with silica gel 200-425 mesh.

Trimethylsilylmethylbenzotriazole $\mathbf{1}$ was synthesized according to the procedure already reported. ${ }^{10}$ Compound $3 \mathbf{e}$ was prepared according to the reported procedure ${ }^{6}$. Compounds $\mathbf{3 f}$ and $3 \mathbf{g}$ were prepared according to the reported procedure ${ }^{11}$.

\section{General procedure for the preparation of $\alpha$-(benzotriazol-1-yl)alkyl ketones (3)} 1-[(Trimethylsilyl)methyl]-1H-1,2,3-benzotriazole (1) $(2.05 \mathrm{~g}, 10 \mathrm{mmol})$ was dissolved in the corresponding acyl chloride $(10 \mathrm{mmol})$ at $40-50{ }^{\circ} \mathrm{C}$. After $10-20 \mathrm{~s}$ the evolution of chlorotrimethylsilane was observed and the mixture began to solidify. The solid obtained was triturated with ether, filtered off and recrystallized from benzene/hexanes to afford an analytically pure sample. 
1-(Benzotriazol-1-yl)-3-phenylacetone (3a). White prisms (chloroform/ hexanes), mp 112-113 ${ }^{\circ} \mathrm{C}(66 \%) ;{ }^{1} \mathrm{H}$ NMR $\delta 3.78$ (s, 2H), 5.43 (s, 2H), 7.13-7.18 (m, 3H), 7.26-7.41 (m, 5H), $8.05(\mathrm{~d}, J=7.9 \mathrm{~Hz}, 1 \mathrm{H}) ;{ }^{13} \mathrm{C}$ NMR $\delta 47.2,55.3,109.0,119.9,124.0,127.6,127.8,129.0,129.2$, 132.1, 133.3, 145.8, 199.5. Anal. Calcd for $\mathrm{C}_{15} \mathrm{H}_{13} \mathrm{~N}_{3} \mathrm{O}: \mathrm{N}, 16.73$. Found: $\mathrm{N}, 16.69$.

1-(Benzotriazol-1-yl)-3-(4-chlorophenyl)acetone (3b). White prisms (ether), mp $112113{ }^{\circ} \mathrm{C}$ (75\%); ${ }^{1} \mathrm{H}$ NMR $\delta 3.75(\mathrm{~s}, 2 \mathrm{H}), 5.45(\mathrm{~s}, 2 \mathrm{H}), 7.06(\mathrm{~d}, J=8.4 \mathrm{~Hz}, 2 \mathrm{H}), 7.18-7.30(\mathrm{~m}, 3 \mathrm{H})$, 7.36-7.52 (m, 2H), $8.08(\mathrm{~d}, J=8.2 \mathrm{~Hz}, 1 \mathrm{H}) ;{ }^{13} \mathrm{C}$ NMR $\delta$ 46.3, 55.6, 108.8, 120.2, 124.2, 128.0, 129.1, 130.3, 130.5, 133.4, 133.7, 145.9, 199.3. Anal. Calcd for $\mathrm{C}_{15} \mathrm{H}_{12} \mathrm{ClN}_{3} \mathrm{O}$ : N, 14.71. Found: N, 14.65 .

1-(Benzotriazol-1-yl)-2-butanone (3c). White prisms (chloroform/ hexanes), mp $109110^{\circ} \mathrm{C}$ $(68 \%) ;{ }^{1} \mathrm{H}$ NMR $\delta 1.09$ (t, $\left.J=7.2 \mathrm{~Hz}, 3 \mathrm{H}\right), 2.48$ (q, $\left.J=7.2 \mathrm{~Hz}, 2 \mathrm{H}\right), 5.44(\mathrm{~s}, 2 \mathrm{H}), 7.36-7.42$ (m, 2H), 7.47-7.53 (m, 1H), $8.08(\mathrm{~d}, J=8.9 \mathrm{~Hz}, 1 \mathrm{H}) ;{ }^{13} \mathrm{C} \mathrm{NMR} \delta$ 7.1, 33.1, 56.0, 109.1, 120.1, 124.1, 127.9, 133.4, 145.8, 202.7. Anal. Calcd for $\mathrm{C}_{10} \mathrm{H}_{11} \mathrm{~N}_{3} \mathrm{O}$ : N, 22.21. Found: $\mathrm{N}, 22.10$.

1-(Benzotriazol-1-yl)-2-pentanone (3d). White prisms (chloroform/ hexanes), mp 106-107 ${ }^{\circ} \mathrm{C}$ $(85 \%) ;{ }^{1} \mathrm{H}$ NMR $\delta 0.71(\mathrm{t}, J=7.4 \mathrm{~Hz}, 3 \mathrm{H}), 1.41-1.48(\mathrm{~m}, 2 \mathrm{H}), 2.26(\mathrm{t}, J=7.2 \mathrm{~Hz}, 2 \mathrm{H}), 5.23(\mathrm{~s}$, 2H), 7.16-7.21 (m, 2H), 7.26-7.31 (m, 1H), $7.87(\mathrm{~d}, J=8.6 \mathrm{~Hz}, 1 \mathrm{H}){ }^{13} \mathrm{C}$ NMR $\delta 13.4,16.6$, 41.6, 56.2, 109.1, 120.0, 124.0, 127.8, 133.3, 145.7, 202.1. Anal. Calcd for $\mathrm{C}_{11} \mathrm{H}_{13} \mathrm{~N}_{3} \mathrm{O}: \mathrm{N}, 20.68$. Found: N, 20.76.

General procedure for the preparation of 2,3,5-trisubstituted phenols 9a-e, 10a-d and 11c-d $\alpha$-(Benzotriazol-1-yl)alkyl ketones 3, potassium tert-butoxide (2 equiv) and the corresponding chalcones ( 1 equiv) were refluxed in $n$-butanol for $48 \mathrm{~h}$. The resulting mixture was acidified, extracted with ethyl acetate $(2 \times 15 \mathrm{~mL})$, washed with brine and purified by column chromatography.

2-Methyl-3,5-bis(4-methylphenyl)phenol (9a). Reddish oil (hexanes/ethyl acetate, 4:1), (48\%); ${ }^{1} \mathrm{H}$ NMR $\delta 2.10(\mathrm{~s}, 3 \mathrm{H}), 2.29$ (s, 3H), 2.33 (s, 3H), $4.94(\mathrm{~s}, 1 \mathrm{H}), 6.93(\mathrm{~s}, 1 \mathrm{H}), 7.00(\mathrm{~s}, 1 \mathrm{H})$, 7.12-7.16 (m, 6H), $7.39(\mathrm{~d}, J=7.9 \mathrm{~Hz}, 2 \mathrm{H}) ;{ }^{13} \mathrm{C}$ NMR $\delta 12.9,21.1,21.2,112.1,120.4,121.2$, 126.7, 128.8, 129.2, 129.4, 136.6, 137.0, 137.7, 138.7, 139.3, 143.9, 154.3. HRMS. Calcd for $\mathrm{C}_{21} \mathrm{H}_{21} \mathrm{O}(\mathrm{M}+1): 289.1592$. Found: 289.1590 .

2,3,5-Triphenylphenol (9b). Reddish orange plates (hexanes/ethyl acetate, 5:1), mp 152.1-153.8 ${ }^{\circ} \mathrm{C}$ (89\%), (lit. $\left.{ }^{4} \mathrm{mp} 162-163{ }^{\circ} \mathrm{C}\right) ;{ }^{1} \mathrm{H}$ NMR $\delta 5.22$ (s, 1H), 7.05-7.40 (m, 15H), 7.45 $(\mathrm{t}, J=7.6 \mathrm{~Hz}, 1 \mathrm{H}), 7.67(\mathrm{~d}, J=7.0 \mathrm{~Hz}, 1 \mathrm{H}) ;{ }^{13} \mathrm{C} \mathrm{NMR} \delta 113.0,116.5,121.3,126.5,127.1$, 127.6, 127.7, 127.8, 128.8, 129.1, 129.6, 130.9, 134.8, 140.4, 141.9, 142.6, 153.2, 154.5. HRMS. Calcd for $\mathrm{C}_{24} \mathrm{H}_{18} \mathrm{O}: 322.1358$. Found: 322.1387 .

3,5-bis(4-Methylphenyl)-2-phenylphenol (9c). Reddish orange plates (hexanes/ethyl acetate, 4:1), mp 156.5-157.9 ${ }^{\circ} \mathrm{C}(43 \%) ;{ }^{1} \mathrm{H}$ NMR $\delta 2.50$ (s, 3H), 2.60 (s, 3H), 5.25 (s, 1H), 7.10-7.80 $(\mathrm{m}, 15 \mathrm{H}) ;{ }^{13} \mathrm{C}$ NMR $\delta 21.1,21.1,112.5,121.1,125.4,126.9,127.7,128.4,129.1,129.5,130.9$, 135.0, 136.1, 137.4, 137.6, 138.1, 141.8, 142.4, 153.2. HRMS. Calcd for $\mathrm{C}_{26} \mathrm{H}_{22} \mathrm{O}$ : 350.1671 . Found: 350.1677 . 
3,5-Bis(4-methoxyphenyl)-2-phenylphenol (9d). yellow oil (hexanes/ethyl acetate, 4:1), (86\%); ${ }^{1} \mathrm{H}$ NMR $\delta 3.63(\mathrm{~s}, 3 \mathrm{H}), 3.74(\mathrm{~s}, 3 \mathrm{H}), 5.14(\mathrm{~s}, 1 \mathrm{H}), 6.60(\mathrm{~d}, J=8.5 \mathrm{~Hz}, 2 \mathrm{H}), 6.87$ (d, $J=8.5 \mathrm{~Hz}$, $2 \mathrm{H}), 6.93(\mathrm{~d}, J=8.2 \mathrm{~Hz}, 2 \mathrm{H}), 7.00-7.26(\mathrm{~m}, 7 \mathrm{H}), 7.49(\mathrm{~d}, J=8.5 \mathrm{~Hz}, 2 \mathrm{H}) ;{ }^{13} \mathrm{C} \mathrm{NMR} \delta 55.1$, 55.3, 112.1, 113.1, 114.2, 120.8, 125.1, 127.6, 128.0, 129.1, 130.7, 130.9, 132.9, 133.5, 135.1, 141.4, 142.1, 153.2, 158.2, 159.3; HRMS. Calcd for $\mathrm{C}_{26} \mathrm{H}_{22} \mathrm{O}_{3}: 382.1569$. Found: 382.1577.

2-(4-Chlorophenyl)-3,5-bis(4-methylphenyl)phenol (9e). reddish orange plates (hexanes/ethyl acetate, 4:1), mp 173.5-175.8 ${ }^{\circ} \mathrm{C}(42 \%) ;{ }^{1} \mathrm{H}$ NMR $\delta 2.50(\mathrm{~s}, 3 \mathrm{H}), 2.60(\mathrm{~s}, 3 \mathrm{H}), 5.25(\mathrm{~s}, 1 \mathrm{H}), 7.16$ $(\mathrm{s}, 4 \mathrm{H}), 7.30(\mathrm{~d}, J=8.5 \mathrm{~Hz}, 2 \mathrm{H}), 7.38-7.52(\mathrm{~m}, 6 \mathrm{H}), 7.74(\mathrm{~d}, J=8.2 \mathrm{~Hz}, 2 \mathrm{H}) ;{ }^{13} \mathrm{C} \mathrm{NMR} \delta 21.1$, $21.1,112.7,121.3,124.2,126.9,128.6,129.2,129.5,129.5,132.3,133.7,136.4,137.4,137.5$, 137.8, 142.0, 142.6, 153.1, 207.0. HRMS. Calcd for $\mathrm{C}_{26} \mathrm{H}_{21} \mathrm{ClO}$ : 384.1281 Found: 384.1276.

3-(4-Methoxyphenyl)-2-methyl-5-phenylphenol (10a). yellow oil (hexanes/ethyl acetate, 4:1), $(50 \%) ;{ }^{1} \mathrm{H}$ NMR $\delta 2.20(\mathrm{~s}, 3 \mathrm{H}), 3.82(\mathrm{~s}, 3 \mathrm{H}), 5.28(\mathrm{~s}, 1 \mathrm{H}), 6.96(\mathrm{~d}, J=8.2 \mathrm{~Hz}, 2 \mathrm{H}), 7.03(\mathrm{~d}, J=$ $1.8 \mathrm{~Hz}, 1 \mathrm{H}), 7.10(\mathrm{~d}, J=1.8 \mathrm{~Hz}, 1 \mathrm{H}), 7.23-7.33(\mathrm{~m}, 3 \mathrm{H}), 7.39(\mathrm{t}, \mathrm{J}=8.7 \mathrm{~Hz}, 2 \mathrm{H}), 7.56(\mathrm{~d}, J=$ $8.5 \mathrm{~Hz}, 2 \mathrm{H}) ;{ }^{13} \mathrm{C}$ NMR $\delta 12.9,55.3,112.2,113.5,113.7,121.4,126.9,127.2,128.7,130.7$, 134.1, 139.3, 140.6, 143.6, 154.4, 158.6. HRMS. Calcd for $\mathrm{C}_{20} \mathrm{H}_{18} \mathrm{O}_{2}$ : 290.1385. Found: 290.1332.

3-(4-Methoxyphenyl)-2-ethyl-5-phenylphenol (10b). yellow oil (65\%); ${ }^{1} \mathrm{H}$ NMR $\delta 1.06(\mathrm{t}, J=$ $4.5 \mathrm{~Hz}, 3 \mathrm{H}), 2.61(\mathrm{q}, J=4.5 \mathrm{~Hz}, 2 \mathrm{H}), 3.90(\mathrm{~s}, 3 \mathrm{H}), 5.00(\mathrm{~s}, 1 \mathrm{H}), 6.95(\mathrm{~d}, J=8.5 \mathrm{~Hz}, 2 \mathrm{H}), 7.01$ (d, $J=1.8 \mathrm{~Hz}, 1 \mathrm{H}), 7.05(\mathrm{~d}, J=1.8 \mathrm{~Hz}, 1 \mathrm{H}), 7.24-7.34(\mathrm{~m}, 3 \mathrm{H}), 7.36-7.44(\mathrm{~m}, 2 \mathrm{H}), 7.54-7.60(\mathrm{~m}$, $2 \mathrm{H}) ;{ }^{13} \mathrm{C}$ NMR $\delta 14.4,20.2,55.3,112.7,113.4,121.7,126.9,127.2,127.4,128.7,130.1,134.2$, 139.3, 140.5, 143.5, 154.1, 158.6. HRMS. Calcd for $\mathrm{C}_{21} \mathrm{H}_{20} \mathrm{O}_{2}: 304.1542$. Found: 304.1545.

Mixture of 3-(4-Chlorophenyl)-5-(4-methylphenyl)-2-phenylphenol (10c) and 5-(4chlorophenyl)-3-(4-methylphenyl)-2-phenylphenol (11c). Molar ratio 10c:11c = 4:1. Colorless oil (hexanes/ethyl acetate, 5:1) (49\%); ${ }^{1} \mathrm{H}$ NMR (10c) $\delta 2.27$ (s, 3H), 5.10 (b.s, 1H), 6.85-6.93 (m, 2H), 6.99-7.28 (m, 11H), 7.43 (d, J = 7.9 Hz, 2H); (11c) $\delta 2.14$ (s, 3H), 5.10 (b.s, 1H), 6.85-6.93 (m, 2H), 6.99-7.28 (m, 11H), $7.43(\mathrm{~d}, J=7.9 \mathrm{~Hz}, 2 \mathrm{H}) ;{ }^{13} \mathrm{C}$ NMR (Superposition of 10c and 11c) $\delta 21.0,21.1,112.6,113.1,120.8,121.0,125.4,126.0,126.8,127.7,127.9,128.2$, $128.4,128.7,128.9,129.1,129.2,129.4,129.5,130.9,132.5,133.6,134.6,134.8,136.2,137.3$, 137.5, 137.9, 138.9, 139.5, 140.4, 141.2, 141.9, 142.7, 153.3; Anal. Calcd for $\mathrm{C}_{25} \mathrm{H}_{19} \mathrm{ClO}$ : C, 80.96. H, 5.17. Found: C, 81.16; H, 5.47.

Mixture of 5-(4-Methylphenyl)-2-phenyl-3-(2-thienyl)phenol (10d) and 3-(4-methyl phenyl)2-phenyl-5-(2-thienyl)phenol (11d). Molar ratio 10d:11d $=1.6: 1$. Colorless oil (hexanes/ethyl acetate, 5:1) (69\%); ${ }^{1} \mathrm{H}$ NMR $(\mathbf{1 0 d}) \delta 2.23(\mathrm{~s}, 3 \mathrm{H}), 5.00(\mathrm{~s}, 1 \mathrm{H}), 6.52(\mathrm{~d}, J=3.6 \mathrm{~Hz}, 1 \mathrm{H}), 6.64(\mathrm{t}$, $J=5.0 \mathrm{~Hz}, 1 \mathrm{H}), 6.79-6.95(\mathrm{~m}, 2 \mathrm{H}), 7.00(\mathrm{~d}, J=6.7 \mathrm{~Hz}, 1 \mathrm{H}), 7.04-7.14(\mathrm{~m}, 5 \mathrm{H}), 7.18-7.25(\mathrm{~m}$, 2H), $7.28(\mathrm{~s}, 1 \mathrm{H}), 7.40(\mathrm{~d}, J=8.1 \mathrm{~Hz}, 1 \mathrm{H}) ;(\mathbf{1 1 d}) \delta 2.10(\mathrm{~s}, 3 \mathrm{H}), 5.11(\mathrm{~s}, 1 \mathrm{H}), 6.79-6.95(\mathrm{~m}, 2 \mathrm{H})$, $7.00(\mathrm{~d}, J=6.7 \mathrm{~Hz}, 1 \mathrm{H}), 7.04-7.14(\mathrm{~m}, 5 \mathrm{H}), 7.18-7.25(\mathrm{~m}, 3 \mathrm{H}), 7.28(\mathrm{~s}, 1 \mathrm{H}), 7.40(\mathrm{~d}, J=8.1$ $\mathrm{Hz}, 2 \mathrm{H}$ ); ${ }^{13} \mathrm{C}$ NMR (Superposition of 10d and 11d) $\delta 20.9,21.0,111.5,113.1,120.1,120.8$, 123.4 , 124.9, 125.2, 125.5, 125.9, 126.6, 126.8, 126.8, 127.6, 127.9, 128.3, 128.4, 129.0, 129.2, 129.4, 129.4, 130.8, 130.9, 134.6, 134.7, 134.8, 136.2, 137.2, 137.4, 137.7, 141.9, 142.6, 142.7, 143.6, 153.2, 153.5. Anal. Calcd for $\mathrm{C}_{23} \mathrm{H}_{18} \mathrm{OS}$ : C, 80.66; H, 5.31. Found: C, 80.66; H, 5.28. 
Preparation of 3-(1H-1,2,3-benzotriazol-1-yl)-2-butanone (4). To a solution of 1-(1H-1,2,3benzotriazol-1-yl)propan-2-one (1 equiv) and MeI (1.5 equiv) in acetonitrile, aqueous $5 \mathrm{M}$ $\mathrm{NaOH}$ ( 3 equiv) was added, and the reaction mixture was stirred at room temperature for $12 \mathrm{~h}$. Then acetonitrile was removed in vacuo, and the oil residue was purified by column chromatography (hexanes/ethyl acetate, 10:1) to afford the pure sample 4 (85\%) as a yellow oil: ${ }^{1} \mathrm{H}$ NMR $\delta 1.93(\mathrm{~d}, J=7.5 \mathrm{~Hz}, 3 \mathrm{H}), 2.04$ (s, 3H), 5.62 (q, $\left.J=7.2 \mathrm{~Hz}, 1 \mathrm{H}\right), 7.35-7.54(\mathrm{~m}, 3 \mathrm{H})$, 8.10( d, $J=8.4 \mathrm{~Hz}, 1 \mathrm{H}) ;{ }^{13} \mathrm{C}$ NMR $\delta 15.3,26.2,63.3,109.4,120.4,124.1,127.7,132.3,146.0$, 202.9. Anal. Calcd for $\mathrm{C}_{10} \mathrm{H}_{11} \mathrm{~N}_{3} \mathrm{O}$ : C, 63.48; H, 5.86; N, 22.21. Found: C, 63.15; H, 6.16; N, 22.33 .

\section{General procedure for the preparation of meta-acylphenols 12a-e and 8}

To a solution of $\alpha$-(benzotriazol-1-yl)ketone (1 equiv) and the corresponding 2,5-diketone (1 equiv) in acetonitrile, aqueous $5 \mathrm{M} \mathrm{NaOH}$ (3 equiv) was added. The reaction mixture was stirred at room temperature for $12 \mathrm{~h}$. Acetonitrile was removed in vacuo, and the oil residue was purified by column chromatography to afford the pure sample.

1-(3-Hydroxy-5-methylphenyl)-1-ethanone (12a). Yellow plates (hexanes /ethyl acetate, 5:1), mp 122-123 ${ }^{\circ} \mathrm{C}(33 \%)$, (lit. $\left.{ }^{9 \mathrm{c}} \mathrm{mp} 122-123{ }^{\circ} \mathrm{C}\right) ;{ }^{1} \mathrm{H}$ NMR $\delta 2.34$ (s, 3H), 2.57 (s, 3H), 6.93 (s, 1H), 7.32 (s, 2H); ${ }^{13} \mathrm{C}$ NMR $\delta 21.5,27.0,112.3,121.7,121.9,138.4,140.3,156.5,199.8$.

(5-Hydroxy[1,1'-diphenyl]-3-yl)(phenyl)methanone (12b). Yellow plates (hexanes /ethyl acetate, 5:1), $\mathrm{mp} 76-77{ }^{\circ} \mathrm{C}(90 \%) ;{ }^{1} \mathrm{H}$ NMR $\delta 7.25-7.53(\mathrm{~m}, 11 \mathrm{H}), 7.89(\mathrm{~d}, J=7.2 \mathrm{~Hz}, 2 \mathrm{H}), 7.94$ (b.s, $1 \mathrm{H}) ;{ }^{13} \mathrm{C}$ NMR $\delta 116.0,119.0,121.4,127.2,128.0,128.5,129.0,130.4,133.1,137.2,139.1$, 139.8, 143.0, 156.8, 198.2. Anal. Calcd for $\mathrm{C}_{19} \mathrm{H}_{14} \mathrm{O}: \mathrm{C}, 83.19$; H, 5.14. Found: C, 82.98; H, 5.48 .

(5-Hydroxy-6-methyl[1,1'-biphenyl]-3-yl)(phenyl)methanone(12c). Yellow plates (hexanes /ethyl acetate, 5:1), mp 92-94 ${ }^{\circ} \mathrm{C}(84 \%) ;{ }^{1} \mathrm{H}$ NMR $\delta 2.23(\mathrm{~s}, 3 \mathrm{H}) 7.21(\mathrm{~s}, 1 \mathrm{H}), 7.26-7.41(\mathrm{~m}$, $7 \mathrm{H}), 7.50(\mathrm{t}, J=7.2 \mathrm{~Hz}, 1 \mathrm{H}), 7.58(\mathrm{~s}, 2 \mathrm{H}), 7.79(\mathrm{~d}, J=7.2 \mathrm{~Hz}, 2 \mathrm{H}) ;{ }^{13} \mathrm{C} \mathrm{NMR} \delta 13.9,115.1$, 124.8, 127.3, 128.3, 128.4, 128.8, 129.4, 130.3, 132.7, 135.3, 137.7, 141.1, 143.5, 155.2, 197.8. Anal. Calcd for $\mathrm{C}_{20} \mathrm{H}_{16} \mathrm{O}: \mathrm{C}, 83.31 ; \mathrm{H}, 5.59$. Found: C, 83.00; H, 5.72.

(6-Butyl-5-hydroxy[1,1'-diphenyl]-3-yl)(phenyl)methanone (12d). Orange plates (hexanes/ethyl acetate, 5:1), mp 64-66 ${ }^{\circ} \mathrm{C}(62 \%) ;{ }^{1} \mathrm{H}$ NMR $\delta 0.78(\mathrm{t}, J=7.3 \mathrm{~Hz}, 3 \mathrm{H}), 1.29-1.18$ $(\mathrm{m}, 2 \mathrm{H}), 1.54-1.43(\mathrm{~m}, 2 \mathrm{H}), 2.62(\mathrm{t}, J=7.8 \mathrm{~Hz}, 2 \mathrm{H}), 6.27(\mathrm{~s}, 1 \mathrm{H}), 7.19(\mathrm{~s}, 1 \mathrm{H}), 7.61-7.25(\mathrm{~m}$, 9H), $7.82(\mathrm{~d}, J=7.2 \mathrm{~Hz}, 2 \mathrm{H}) ;{ }^{13} \mathrm{C}$ NMR $\delta 13.9,23.0,27.3,31.9,115.5,125.2,127.4,128.3$, $128.5,129.3,130.3,132.6,133.4,135.5,137.8,141.3,143.6,154.7,197.0$. HRMS. Calcd for $\mathrm{C}_{23} \mathrm{H}_{22} \mathrm{O}_{2}: 330.1620$. Found: 330.1573 .

(6-Benzyl-5-hydroxy[1,1'-diphenyl]-3-yl)(phenyl)methanone (12e). Orange plates (hexanes/ethyl acetate, 5:1), mp 86-88 ${ }^{\circ} \mathrm{C}(40 \%) ;{ }^{1} \mathrm{H}$ NMR $\delta 4.07$ (s, 2H), 5.35 (b.s, 1H), 7.07 $(\mathrm{d}, J=6.9 \mathrm{~Hz}, 2 \mathrm{H}), 7.14-7.28(\mathrm{~m}, 6 \mathrm{H}), 7.32-7.36(\mathrm{~m}, 4 \mathrm{H}), 7.47(\mathrm{t}, J=7.5 \mathrm{~Hz}, 2 \mathrm{H}), 7.57(\mathrm{t}, J=$ $7.2 \mathrm{~Hz}, 1 \mathrm{H}), 7.84(\mathrm{~d}, J=7.2 \mathrm{~Hz}, 2 \mathrm{H}) ;{ }^{13} \mathrm{C}$ NMR $\delta 33.3,116.2,125.1,126.6,127.6,128.4,128.4$, 128.5, 128.8, 129.3, 129.8, 130.2, 132.6, 136.8, 137.8, 139.7, 140.7, 144.4, 154.8, 196.4. HRMS. Calcd for $\mathrm{C}_{26} \mathrm{H}_{20} \mathrm{O}_{2}$ : 364.1443 . Found: 364.1463 . 
(5-Hydroxy-4-methyl[1,1'-biphenyl]-3-yl)(phenyl)methanone (8). Yellow plates (hexanes/ethyl acetate, 5:1), mp $95-97{ }^{\circ} \mathrm{C}(50 \%) .{ }^{1} \mathrm{H}$ NMR $\delta 2.18(\mathrm{~s}, 3 \mathrm{H}), 6.28(\mathrm{~s}, 1 \mathrm{H})$, $7.09(\mathrm{~d}, J=1.2 \mathrm{~Hz}, 1 \mathrm{H}), 7.15(\mathrm{~d}, J=1.2 \mathrm{~Hz}, 1 \mathrm{H}), 7.23-7.36(\mathrm{~m}, 3 \mathrm{H}), 7.47-7.41(\mathrm{~m}, 4 \mathrm{H})$, $7.58(\mathrm{t}, J=7.5 \mathrm{~Hz}, 1 \mathrm{H}), 7.87(\mathrm{~d}, J=7.5 \mathrm{~Hz}, 2 \mathrm{H}) ;{ }^{13} \mathrm{C}$ NMR $\delta 12.9,115.6,119.1,121.9,127.0$, 127.7, 128.8, 128.9, 130.5, 133.8, 137.5, 139.7, 140.0, 141.0, 155.1, 199.4. Anal. Calcd for $\mathrm{C}_{20} \mathrm{H}_{16} \mathrm{O}: \mathrm{C}, 83.31 ; \mathrm{H}, 5.59$. Found: $\mathrm{C}, 83.40 ; \mathrm{H}, 5.36$.

\section{References}

1. (a) Saito, S.; Yamamoto, H. Chem. Commun. 1997, 1585. (b) Thorn, M. G.; Vilardo, J. S.; Fanwick, P. E.; Rothwell, I. P. Chem. Commun. 1998, 2427. (c) Vilardo, J. S.; Thorn, M. G.; Fanwick, P. E.; Rothwell, I. P. Chem. Commun. 1998, 2425. (d) Saito, S.; Kano, T.; Hatanaka, K.; Yamamoto, H. J. Org. Chem. 1997, 62, 5651.

2. (a) Letcher, R. M.; Wong, M.-C. J. Chem. Soc., Perkin Trans. 1 1992, 3035. (b) Bubb, W. A.; Sternhell, S. Tetrahedron Lett. 1970, 4499. (c) McKillop, A.; Perry, D. H.; Edwards, M.; Antus, S.; Farkas, L.; Nogradi, M.; Taylor, E. C. J. Org. Chem. 1976, 41, 282. (d) Majetich, G.; Zhang, Y. J. Am. Chem. Soc. 1994, 116, 4979.

3. (a) Bergeron, D.; Brassard, P. Heterocycles 1992, 34, 1835. (b) Brimble, M. A.; Phythian, S. J. Tetrahedron Lett. 1993, 34, 5813. (c) Magnus, P.; Eisenbeis, S. A.; Magnus, N. A. J. Chem. Soc., Chem. Commun. 1994, 1545. (d) Nicolaou, K. C.; Gross, J. L.; Kerr, M. A.; Lemus, R. H.; Ikeda, K.; Ohe, K. Angew. Chem., Int. Ed. 1994, 33, 781.

4. Von Dimroth, K.; Laubert, G.; Blöcher, K. H. Liebigs Ann. Chem. 1972, 765, 133.

5. Ried, W.; König, E. Liebigs Ann. Chem. 1972, 757, 153.

6. Katritzky, A. R.; Belyakov, S. A.; Henderson S. A. J. Org. Chem. 1997, 62, 8215.

7. (a) Downes, A. M.; Gill, N. S.; Lions, F. J. Am. Chem. Soc. 1950, 72, 3464. (b) Zimmerman, H. E.; Schuster, D. I. J. Am. Chem. Soc. 1962, 84, 4527.

8. Eichinger, K.; Nussbaumer, P.; Balkan, S.; Schulz, G. Synthesis 1987, 1061.

9. (a) Da Re, P.; Cimatoribus, L. J. Org. Chem. 1961, 26, 3650. (b) Kloetzel, M. C.; Dayton, R. P.; Herzog, H. L. J. Am. Chem. Soc. 1950, 72, 273. (c) Baldwin, J. E.; Lusch, M. J. Tetrahedron 1982, 38, 2939.

10. Katritzky, A. R.; Lam, J. N. Heteroatom. Chem. 1990, 1, 21.

11. Katritzky, A. R.; Wang, J.; Karodia, N.; Li, J. J. Org. Chem. 1997, 62, 4142. 